\title{
Bladder Sparing Surgical Treatment in a Patient with Pelvic Lipomatosis
}

\section{Pelvik Lipomatozisli Bir Olguda Mesane Koruyucu Cerrahi Tedavi}

\author{
(1) Fatih Tarhan1, (1) Övünç Kavukoğlu22, (1) Utku Can1, (1) Aydın Özgül3 \\ 1 University of Health Sciences, Kartal Dr. Lütfi Kırdar Training and Research Hospital, Clinic of Urology, Istanbul, Turkiye \\ 2 Gümüşhane State Hospital, Clinic of Urology, Gümüşhane, Turkiye \\ ${ }^{3}$ Ersoy Private Hospital, Clinic of Urology, Istanbul, Turkiye
}

\begin{abstract}
Pelvic lipomatosis is an uncommon benign disease characterized by the excessive growth of mature fat tissue in the perivesical and perirectal areas. A 61-year-old male patient, who was admitted with voiding difficulty, underwent bladder-sparing surgery with excision of adipose tissue for pelvic lipomatosis. The case is presented and discussed with the relevant literature.
\end{abstract}

Keywords: Pelvic lipomatosis, Treatment, Surgery

\section{$\ddot{0 z}$}

Pelvik lipomatozis, perivezikal ve perirektal bölgelerde aşırı matür yağ dokusu büyümesi ile karakterize nadir ve benign bir hastalıktır. İdrar yapma zorluğu ile başvuran 6 yaşındaki erkek hastaya pelvik lipomatosis için mesane koruyucu yağ doku eksizyonu cerrahisi uygulandı. Olgu ilgili literatür eşliğinde sunuldu ve tartışıldı.

Anahtar Kelimeler: Pelvik lipomatozis, Tedavi, Cerrahi

\section{Introduction}

Pelvic lipomatosis is a benign proliferative disease characterized by excessive growth of large amounts of mature fat tissue often accompanied by cell infiltration and fibrosis in the pelvic retroperitoneal space $(1,2)$. It was first defined by Engels $(3)$ in 1959 and was termed "pelvic lipomatosis" by Fogg and Smyth (4) in 1968. Until 2005, 198 cases had been reported (5). The PubMed screening showed that additional 116 cases in a total of 18 studies have been published since 2005 (6). The incidence pelvic lipomatosis has been reported to be $0.6-1.7$ per 100.000 hospital admissions in the USA (7). The male-female ratio of pelvic lipomatosis ranges between 10:1 and 27:1 $(2,5,8,9)$. Heyns et al. reported that the mean age at diagnosis was 48 years with a range from 9 to 80 years (2). Tong et al. reported that pelvic lipomatosis was seen in the same family members (10) and was more common in blacks, but this is uncertain (11).
The etiology of pelvic lipomatosis is not clear $(2,9)$. Obesity, endocrine disorders, posterior urethral obstruction, recurrent urinary system infections, and steroid treatment have been proposed to be possible mechanisms $(2,9)$. Finally, it may be related to an anomaly in the HMG-IC gene (10) or significant changes in the whole genome methylation level (12).

Symptoms are caused by extrinsic compression of the urinary system, the lower intestinal tract and the vascular system $(2,9)$. There are no disease-specific findings in the physical examination $(2,9)$.

The methods used in the diagnosis of pelvic lipomatosis are computed tomography (CT) and magnetic resonance imaging $(1,8)$. There are bilaterally compressed, fixed, superiorly and anteriorly dislocated bladder (inverted tear-drop, pear, gourd or banana-shaped), superomedially displaced lower third part of the ureter, prolongation and anterior displacement

Correspondence: Fatih Tarhan MD, University of Health Sciences, Kartal Dr. Lütfi Kırdar Training and Research Hospital, Clinic of Urology, İstanbul, Turkiye Phone: +90 5327223435 E-mail: tarhanf@yahoo.com ORCID-ID: orcid.org/0000-0001-8168-0420

Received: 02.11.2019Ａccepted: 15.11.2019

Cite this article as: Tarhan F, Kavukoğlu Ö, Can U, Özgül A. Bladder Sparing Surgical Treatment in a Patient with Pelvic Lipomatosis. J Urol Surg 2020;7(1):61-

๑Copyright 2020 by the Association of Urological Surgery / Journal of Urological Surgery published by Galenos Publishing House. 
of the prostatic urethra by increased adipose tissue, besides hydroureteronephrosis $(1,8)$. When pelvic lipomatosis coexists with cystitis glandularis, filling defects may be seen in the related bladder wall $(1,2)$. We present herein a case of a 61-year-old man with pelvic lipomatosis treated by bladder-sparing surgery and discuss the relevant literature.

\section{Case Report}

A 61-year-old male patient presented with the complaints of slow urine stream and frequency. He had a history of urolithiasis surgery and hypertension. The patient's body mass index was $43 \mathrm{~kg} / \mathrm{m} 2$. On digital rectal examination, the prostate was unremarkable. The patient's blood creatinine, urea nitrogen, and total prostate-specific antigen values were $2.5 \mathrm{mg} / \mathrm{dL}, 50 \mathrm{mg} / \mathrm{dL}$ and $2.2 \mathrm{ng} / \mathrm{mL}$, respectively. Urinalysis revealed hematuria and pyuria. Urine culture and tuberculosis test were negative.

Non-contrast abdominal CT revealed bilateral grade 4 hydronephrosis, cranially displaced bladder and increased pelvic adipose tissue (Figure 1a, 1b). On nephrostogram, no contrast passage from the right ureter to the urinary bladder and from the left kidney to the left ureter was observed (Figure 1c, 1d). There was no reflux on voiding cystourethrography (Figure 2). Detrusor overactivity and outflow obstruction were detected in pressure-flow study. Histopathological examination of the bladder biopsy specimens revealed follicular cystitis.

Subsequently, the fatty tissue surrounding the bladder was excised preserving the bladder and by employing a previously described technique (13). Histopathological examination

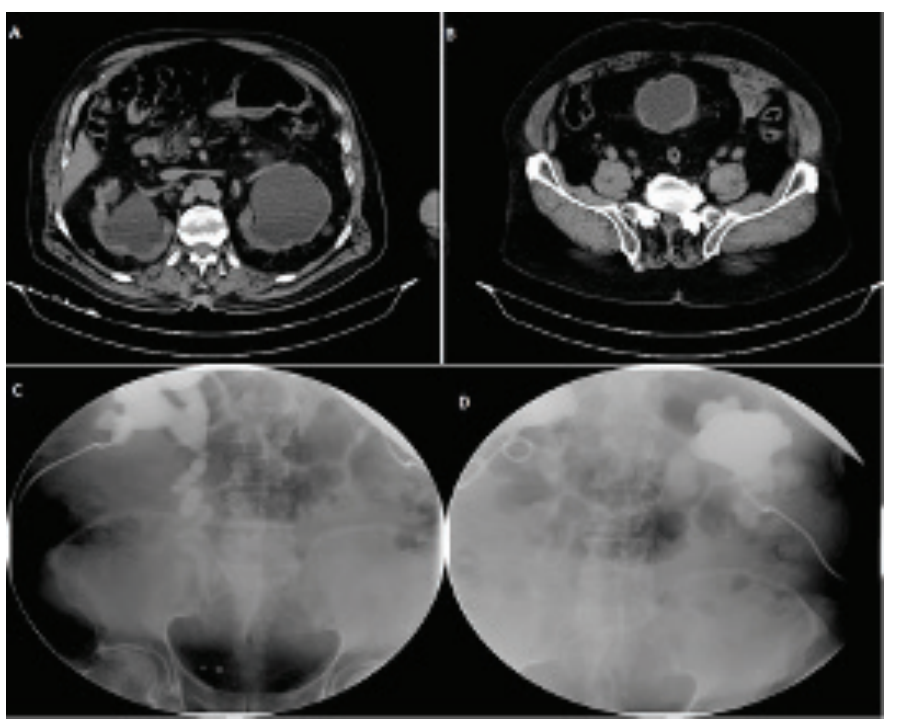

Figure 1. Non-contrast abdominal computed tomography. A) Bilateral grade 4 hydronephrosis. B) High-density perivesical adipose tissue and cranially replacement of the urine bladder. The nephrostography. C) A very tortuous right ureter, and no contrast passage from the right distal ureter to the urine bladder. D) There is no ureteral contrast passage from the left kidney

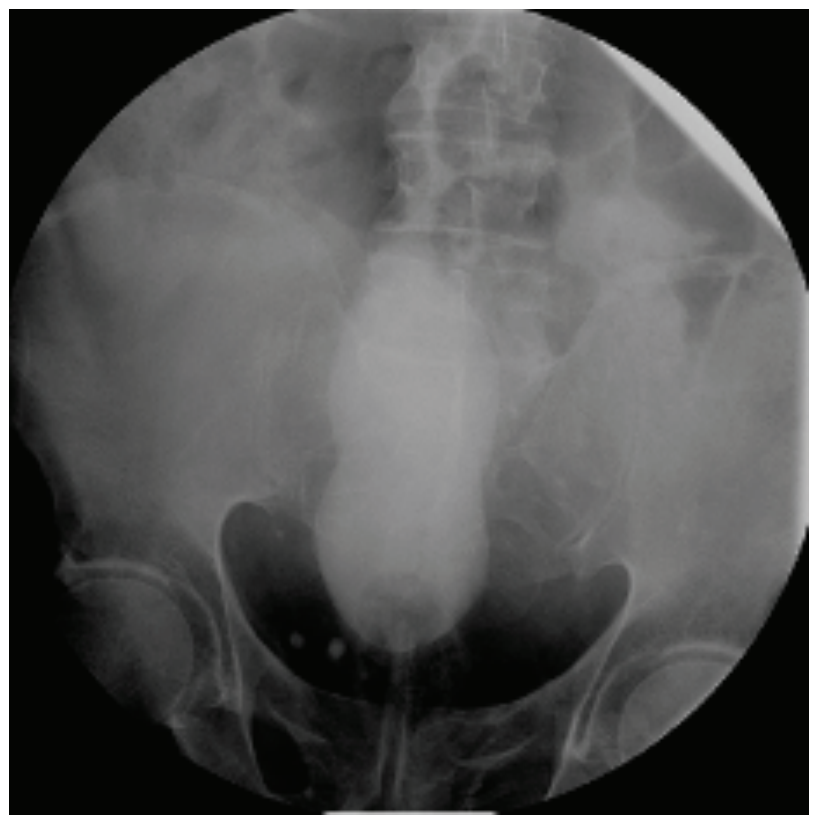

Figure 2. The urine bladder form is impaired, craniocaudal length is increased, and vesicoureteral reflux is absent on the cystogram

revealed mature adipose tissue development. Four months after surgery, post-void residual urine volume and serum creatinine value were $45 \mathrm{cc}$ and $1.66 \mathrm{mg} / \mathrm{dL}$, respectively. There were grade 1 hydronephrosis of the right kidney and grade 2 hydronephrosis of the left kidney in the three-year follow-up of the patient. Voiding difficulty and the quality of life of the patient improved after the operation. Control cystoscopy could not be performed because of patient refusal.

A written informed consent from patient was obtained.

\section{Discussion}

Pelvic lipomatosis has serious complications such as obstructive renal failure $(2,5,9)$, hypertension $(2,9)$, thrombosis, urinary calculi, and bladder adenocarcinoma $(2,9,14)$. Approximately three-quarters of cases of pelvic lipomatosis have been reported to be associated with proliferative cystitis, a premalignant lesion, such as cystitis glandularis, cystitis cystica, or cystitis follicularis $(2,9,10,11,14)$.

Differential diagnostic considerations include pelvic hematoma, urinoma, extensively enlarged lymph nodes, lymphoma, liposarcoma, a large lymphocele, pelvic venous collaterals formed by inferior vena cava obstruction, and abscess or iliopsoas hypertrophy $(1,2,9)$.

In their study including 84 patients with pelvic lipomatosis, Chen et al. (11) reported that nearly $80 \%$ of patients had various degrees of bladder outlet obstructions according to urodynamics. None of the non-obstructed patients had disease progression at follow-up (11). 
There is no standardized algorithm for the treatment of pelvic lipomatosis. The efficacy of different treatment modalities such as weight loss, antibiotics, steroids, and radiotherapy has not been proven $(2,9)$. In the management of this disease, a conservative approach is preferred for patients with minor symptoms and without renal impairment $(2,9,13,15)$.

If patients have severe hydronephrosis and uremia, urinary diversion (double J stent placement, ureteral reimplantation, nephrostomy, ureterostomy or conduit) is recommended to prevent renal impairment $(2,5,8,9,11,15)$. The alternative to this approach is removal of the fat tissue in the treatment of pelvic lipomatosis. The first successful treatment of pelvic lipomatosis by extirpation of the lipomas was reported by Carpenter in 1973 (16). Ballesteros reported the second case of perivesical lipomatosis in which the fat deposits were successfully removed surgically in 1977 (17). Halachmi et al. described an ultrasonic-assisted lipectomy technique for the treatment of pelvic lipomatosis (15). Ali et al (13). reported a case of pelvic lipomatosis in a 45-year-old male patient in whom a bladder-sparing excision of the adipose tissue was performed. Recently, Ge et al. reported satisfactory outcomes in their study investigating long-term efficacy of a novel treatment modality for pelvic lipomatosis, a combination of pelvic mass extirpation and ureteral reimplantation (18).

We consider that excision of pelvic adipose tissue using the bladder-sparing technique in suitable patients may give satisfactory results. The procedure can be attempted before major surgery, such as cystectomy and ileal loop diversion, to avoid major surgical interventions.

\section{Ethics}

Informed Consent: A written informed consent from patient was obtained.

Peer-review: Externally peer-reviewed.

\section{Authorship Contributions}

Surgical and Medical Practices: F.T., A.Ö., Concept: F.T., Design: F.T., Data Collection or Processing: Ö.K., U.C., Analysis or Interpretation: F.T., Literature Search: F.T., Writing: F.T., Ö.K., U.C., A.0̈.

Conflict of Interest: No conflict of interest was declared by the authors.

Financial Disclosure: The authors declared that this study received no financial support.

\section{References}

1. Craig WD, Fanburg-Smith JC, Henry LR, Guerrero $R$, Barton JH. Fatcontaining lesions of the retroperitoneum: radiologic-pathologic correlation. Radiographics 2009;29:261-290.

2. Heyns CF. Pelvic lipomatosis: a review of its diagnosis and management. $J$ Urol 1991;146:267-273.

3. Engels EP. Sigmoid colon and urinary bladder in high fixation: roentgen changes simulating pelvic tumor. Radiology 1959;72:419-422.

4. Fogg LB, Smyth JW. Pelvic lipomatosis: a condition simulating pelvic neoplasm. Radiology 1968;90:558-564.

5. Xu T, Zhao WH, Wang XF, Huang XB, Xu QQ, Yang B, Ye XJ. Analysis of pelvic lipomatosis and a case report of two brothers. Beijing Da Xue Xue Bao Yi Xue Ban 2007;39:355-360.

6. https://www.ncbi.nlm.nih.gov/pubmed/?term=\%22pelvic+lipomatosis $\% 22+\#$ facet_date_range_divds1

7. Old WL, Stokes TL. Pelvic lipomatosis. Surgery 1978;83:173-180.

8. Xia S, Yan Y, Peng B, Yang B, Zheng J. Image characteristics of computer tomography urography in pelvic lipomatosis. Int J Clin Exp Med 2014;7:296299.

9. Klein FA, Smith MVJ, Kasenetz I. Pelvic lipomatosis: 35-year experience. J Urol 1988;139:998-1001.

10. Tong RS, Larner T, Finlay M, Agarwal D, Costelᄀlo AJ. Pelvic lipomatosis associated with prolifaerative cystitis occurring in two brothers. Urology 2002;59:602xvii-602xx.

11. Chen $Y$, Yang $Y, Y u$ W, Xiao $Y$, Fan $Y$, Duan J, Tang $Y$, Jin J, Wang $H$, Wang H, Zhu S, Xi Z, Wu S. Urodynamic characteristics of pelvic lipomatosis with glandular cystitis patients correlate with morphologic alterations of the urinary system and disease severity. Neurourol Urodyn 2018;37:758-767.

12. Xiong G, He S, Li X, Han W, Zhou L. Whole genome epigenetic characteristics of pelvic lipomatosis: the new hope to prevent and cure this disease. Eur Urol Suppl 2018;17:e641.

13. Ali A, Swain S, Manoharan M. Pelvic lipomatosis: Bladder sparing extirpation of pelvic mass to relieve bladder storage dysfunction symptoms and pelvic pain. Cent European J Urol 2014;67:287-288.

14. Heyns CF, De Kock ML, Kirsten PH, Van Velden DJJ. Pelvic lipomatosis associated with cystitis glandularis and adenocarcinoma of the bladder. J Urol 1991;145:364-366.

15. Halachmi S, Moskovitz B, Calderon N, Nativ 0. The use of an ultrasonic assisted lipectomy device for the treatment of obstructive pelvic lipomatosis. Urology 1996;48:128-130.

16. Carpenter AA. Pelvic lipomatosis: successful surgical treatment. J Urol 1973;110:397-399.

17. Ballesteros JJ. Surgical treatment of perivesical lipomatosis. J Urol 1977; $118: 329$

18. Ge L, Tian X, Zhao G, Ma J, Song Y, Yang F, Zhang S, Ma L. Surgical treatment for pelvic lipomatosis using a bladder-sparing technique: A STROBEcompliant study. Medicine (Baltimore) 2019;98:e16198. 